\title{
PENDEKATAN GENDER DALAM STUDI ISLAM
}

\author{
Nur Adilah Mahyaddin \\ Pascasarjana Universitas Islam Negeri Yogyakarta \\ Jl. Marsda Adisucipto Kabupaten Sleman Yogyakarta \\ sangaji.jurnal@gmail.com
}

\section{Abstract:}

The term of gender became popular until now, it had been caused by critic to the policy in any Europe Countries such as the policy of problem which happen in employ. It to be different between male and female in job. Meanwhile, Islam ranges Female. In this paper, researcher use the theory of gender to see how Islam range female. Event tough Islamic and Positive Low had ranged details, however many females to be object or subordinat in any situation compared males, finally fameless more violent. So, in this situation, researches think the problem is very important to solve, females not only object of violent but they have fitrah (basic right) to be respected. Hopefully, the term of gender must be understanded clearly and done rightly, so there is not conflict caused by misunderstanding about gender.

Keywords: Gender, Female, Conflict

\section{Pendahuluan}

Al-Qur'an merupakan pedoman hidup bagi setiap umat Islam yang telah mengajarkan untuk menempatkan setiap manusia berada pada posisi yang sederajat (egaliter), tanpa melihat perbedaan, baik dari jenis kelamin, status, sosial, ras, maupun agama. Dikarenakan di mata Allah SWT semua manusia adalah sama dan hanya level ketakwaan yang membedakan diantara mereka, sebagaimana firman Allah SWT dalam surat al Hujurat: 13, yakni:

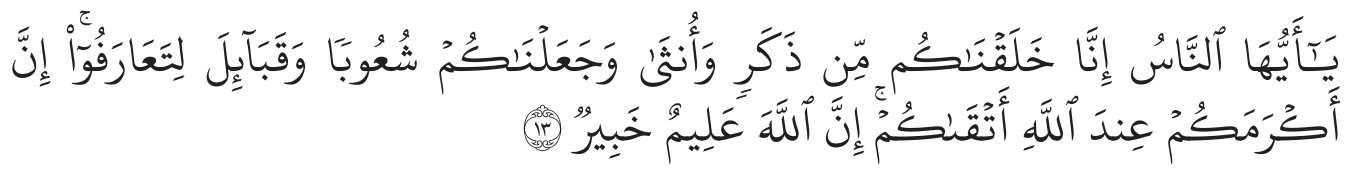

Terjemahannya:

Hai manusia, sesungguhnya Kami menciptakan kamu dari seorang lakilaki dan seorang perempuan dan menjadikan kamu berbangsa-bangsa dan 
bersuku-suku supaya kamu saling kenal-mengenal. Sesungguhnya orang yang paling mulia diantara kamu di sisi Allah ialah orang yang paling takwa diantara kamu. Sesungguhnya Allah Maha Mengetahui lagi Maha Mengenal. (Qs. Al-Hujarat: 13)

Sayangnya, prinsip-prinsip tersebut sering kali dimaknai sebagai pesan yang terkandung dalam al-Qur'an, sehingga seringkali nash-nash hanya dipahami secara tekstual tanpa pemahaman sosio-historisnya.

Di Indonesia, pembicaraan tentang isu perempuan dan gender sangat marak, khususnya setelah tahun 90-an yang ditandai dengan maraknya diskusi, seminar, advokasi, penerbitan, dan sosialisasi yang gencar melalui lembaga swadaya masyarakat yang mengurusi masalah perempuan. Namun, sayangnya perbincangan mengenai isu-isu perempuan di dalam Islam dianggap sudah selesai, tidak memerlukan interpretasi dan formulasi yang baru. Artinya, isu-isu bagi perempuan tersebut dianggap merupakan cermin dari kehendak Tuhan atau kodrat dari Tuhan. Oleh karena itu, perbincangan mengenai isu-isu perempuan di dalam Islam dianggap sudah selesai.

Namun, hal ini justru mengundang banyak pertanyaan, dikarenakan isu-isu mengenai posisi perempuan dan kesetaraan gender sudah menjadi bagian dari isu Hak Asasi Manusia (HAM) dan demokrasi yang dianggap sebagai standar global harus dilaksanakan oleh semua negara di dunia. Gender biasa dikaitkan dengan pembedaan atas dasar jenis kelamin (seks), oleh karena itu dalam pembicaraan gender selalu muncul hubungan antara pria dan wanita. Maka, dapat dikatakan bahwasanya, gender merupakan pembedaan peran, fungsi dan tanggung jawab antara perempuan dan laki-laki yang dihasilkan dari konstruksi social budaya dan dapat berubah sesuai dengan perkembangan zaman. ${ }^{1}$

Hakikatnya perbedaan gender sesungguhnya tidak menjadi masalah sepanjang tidak melahirkan ketidakadilan gender. Namun dalam kenyataannya perbedaan gender telah melahirkan berbagai ketidakadilan terutama bagi kaum perempuan. Ketidakadilan gender dapat dilihat melalui berbagai manifestasi seperti marginalisasi, subordinasi, pembentukan sreotipe (pelabelan), kekerasan (violence) hlm. 3.

${ }^{1}$ Mufidahlm, Psikologi Keluarga Islam Berwawasan Gender, (Malang: UIN Malang Press, 2008),

Sangaji Jurnal Pemikiran Syariah dan Hukum 
maupun beban kerja. ${ }^{2}$

Salah satu contoh konkret dari formulasi agama dalam hal kepemimpinan yang bersumber dari al- Qur'an surat an-Nisa: 34 yang berbunyi:

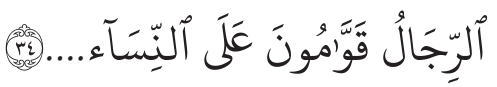

Terjemahannya:

Kaum laki-laki itu adalah pemimpin bagi kaum wanita.

Tidak dapat dipungkiri bahwa penggalan ayat tersebut, menjadi justifikasi ampuh untuk mensubordinatkan peran perempuan dalam kehidupan, sebagai akibatnya, perempuan dianggap manusia kelas kedua dalam realitas sosial.

Demikian juga mengenai pembagian warisan antara laki-laki dan perempuan, sebagaimana dalam surat an-Nisa:11 yakni:

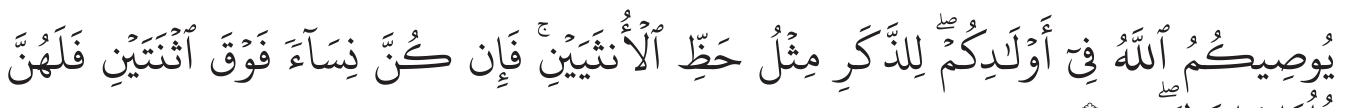

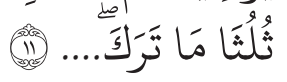

Terjemahannya:

Allah mensyari'atkan bagimu tentang (pembagian pusaka untuk) anakanakmu. Yaitu: bagian seorang anak laki-laki sama dengan bagian dua orang anak perempuan.

Menurut Husein, pembelaan terhadap perempuan kiranya dapat membawa dampak sangat strategis bagi pembangunan manusia. Sebagaimana yang diungkapkan "Banyak yang beranggapan bahwa masalah penindasan terhadap perempuan adalah masalah yang tidak besar, padahal masalah yang dialami dan dihadapi perempuan (ketidakadilan dan subordinasi) adalah masalah besar, karena perempuan adalah bagian dari manusia dan bagian dari jenis kelamin, dan ketika perempuan dijadikan nomor dua maka ini sebenarnya adalah masalah besar bagi kemanusiaan. ${ }^{3}$

${ }^{2}$ Mansour Faqihlm, Analisis Gender dan Transformasi Sosial, (Yogyakarta: Pustaka Pelajar, 2003), hlm. 12.

${ }^{3}$ Nuruzzaman, “Ucapan Terima kasihlm Penuli" dalam HLMusein Muhlmammad, Islam Agama Ramahlm Perempuan Pembelaan Kiai Pesantren, (Yogyakarta: LKIS, 2001), hlm. xxv. 
Dari beberapa paparan tersebut maka, menarik penulis untuk membahasnya dalam jurnal ini tentang "Pendekatan Gender dalam Studi Islam".

\section{Gender dan Prinsip Gender}

Secara bahasa, kata gender berasal dari bahasa Inggris yang berarti jenis kelamin. Dalam Womens Studies Encylopedia, dijelaskan bahwa gender adalah konsep cultural, berupaya membuat pembedaan dalam hal peran, perilaku, mentalitas dan karakteristik emosional antara lakilaki dan perempuan yang berkembang dalam masyarakat. Sedangkan Hillary M. Lips, mengartikan gender sebagai harapan-harapan budaya terhadap laki-laki dan perempuan. ${ }^{4}$

Dalam Kepmendagri No. 132 disebutkan bahwa gender adalah konsep yang mengacu para peran dan tanggung jawab laki-laki dan perempuan yang terjadi akibat dari dan dapat berubah oleh keadaan social dan budaya masyarakat. ${ }^{5}$

Dapat dipahami bahwasanya gender menunjuk pada peranan dan hubungan antara laki-laki dan perempuan. jika perbedaan seks merupakan bawaan sejak lahir dan sepenuhnya kehendak Tuhan, konstruksi gender sepenuhnya atas kreasi dan ciptaan masyarakat. ${ }^{6}$ Untuk lebih jelasnya dapat diperhatikan pada tabel berikut ini:

\section{Tabel 1. Perbedaan Seks dan Gender}

\begin{tabular}{|l|l|l|l|l|}
\hline \multicolumn{1}{|c|}{ Identifikasi } & \multicolumn{1}{|c|}{ Laki-laki } & \multicolumn{1}{c|}{ Perempuan } & \multicolumn{1}{c|}{ Sifat } & \multicolumn{1}{c|}{ Kategori } \\
\hline Ciri Biologis & Penis, & Vagina, & Tetap, & Jenis Kelamin/ \\
& Jakun, & Payudara (ASI), & Seks \\
& Sperma & $\begin{array}{l}\text { Tidak dapat } \\
\text { dipertukarkan, } \\
\text { Kodrati Tuhan }\end{array}$ & \\
& & Rahim, & & \\
& & Haid, & & \\
& & Mamil, \\
& & Melahirkan, \\
& Menyusui & & \\
\hline
\end{tabular}

${ }^{4}$ Mansour Fakihlm, Analisis Gender dan Transformasi Sosial, (Yogyakarta: Pustaka Pelajar, 1999), hlm. 71 hlm. 2

${ }^{5}$ Mufidahlm, Psikologi Keluarga Islam Berwawasan Gender, (Malang: UIN Malang Press, 2008),

6 Musdahlm Mulia, Indahlmnya Islam Menyuarakan Keseteraan \& Keadilahlm Gender, (Yogyakarta: SM \& Naufan Pustaka, 2014), hlm. 66

Sangaji Jurnal Pemikiran Syariah dan Hukum 


\begin{tabular}{|c|c|c|c|c|}
\hline Identifikasi & Laki-laki & Perempuan & Sifat & Kategori \\
\hline Sifat atau Karakter & $\begin{array}{l}\text { Rasional, } \\
\text { Kuat, } \\
\text { Cerdas, } \\
\text { Pemberani, } \\
\text { Superior, } \\
\text { Maskulin }\end{array}$ & $\begin{array}{l}\text { Emosional, } \\
\text { lemah, penakut, } \\
\text { inferior, feminine }\end{array}$ & $\begin{array}{l}\text { Ditentukan oleh } \\
\text { masyarakat, } \\
\text { Disosialisasikan, } \\
\text { Dimiliki oleh laki-laki } \\
\text { dan perempuan, } \\
\text { Dapat berubah sesuai } \\
\text { kebutuhan }\end{array}$ & Gender \\
\hline
\end{tabular}

Berdasarkan tabel tersebut, maka dapat disimpulkan bahwasanya jenis kelamin (seks) tidak akan pernah berubah dari waktu ke waktu. Sementara konsep gender selalu berubah akibat perubahan waktu dan tempat. Gender adalah konstruksi sosial yang dapat diubah sesuai dengan tingkat kesadaran kemanusiaan masyarakat. Inti dari wacana gender itu sendiri adalah persamaan hak. Keadilan gender itu sebenarnya sudah ada, tapi hakikat keadilan gender yang memperkuat persamaan hak antara laki-laki dan perempuan itu dalam pelaksanannya sering kali mengalami distorsi.

\section{Prinsip Kesetaraan dan Keadilan Gender}

Kesetaraan gender adalah posisi yang sama antara laki-laki dan perempuan dalam memperoleh akses, partisipasi, kontrol, dan manfaat dalam aktifitas berbangsa dan bernegara. Sedangkan keadilan gender adalah suatu proses menuju setara, selaras, seimbang, serasi, dan tanpa diskriminasi.

Hakikatnya Islam menempatkan perempuan pada posisi yang sama dengan laki-laki. Kesamaan tersebut dapat dilihat dari beberapa ayat AlQur'an :7

\section{Dari Segi Pengabdian}

Perempuan memiliki kesempatan dan kemampuan yang sama dengan laki-laki untuk menjadi hamba secara ideal menurut al Qur'an seperti yang diungkapkan dalam al Qur'an surat al Hujurat: 13,

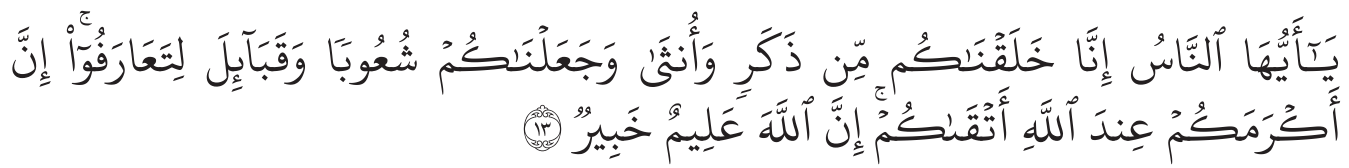

${ }^{7}$ Mansour Fakihlm, Membincang Feminisme Diskursus Gender Perspektif Islam, (Surabaya: Risalahlm Gusti: 1996), hlm. 152-154 
Terjemahannya:

Hai manusia, sesungguhnya kami menciptakan kamu dari seorang lakilaki dan seorang perempuan dan menjadikan kamu berbangsa-bangsa dan bersuku-suku supaya kamu saling kenal-mengenal. Sesungguhnya orang yang paling mulia diantara kamu disisi Allah ialah orang yang paling taqwa diantara kamu. Sesungguhnya Allah maha mengetahui lagi maha mengenal.

Ada dua riwayat yang menyebabkan ayat tersebut turun, yaitu: pertama, dari Ibn Abi Malikah mengatakan, bahwa ketika hari kemenangan, sahabat bilal (berkulit hitam) mengumandangkan azan di Ka'bah. Kemudian diantara para sahabat berkata, “Apakah orang yang berkulit hitam itu lagi, yang sedang adzan? Sebagian mereka berkata, "jika Allah tidak menyukainya, gantikanlah", kemudian turunlah ayat ini. Kedua, ayat tersebut turun disebabkan adanya kasus Abi Hindun, bahwasanya Rasulullah SAW menyuruh orang-orang yang menjadi budak, kemudian mereka bertanya, "ya Rasulullah, apakah anak-anak perempuan kami akan kamu kawinkan dengan mereka?", maka turunlah ayat ini. ${ }^{8}$

\section{Dari Segi Status Kejadian}

Al Qur'an menerangkan bahwa perempuan dan laki-laki diciptakan Allah dalam derajat yang sama, sebagaimana firman Allah dalam surat an-Nisa: 1;

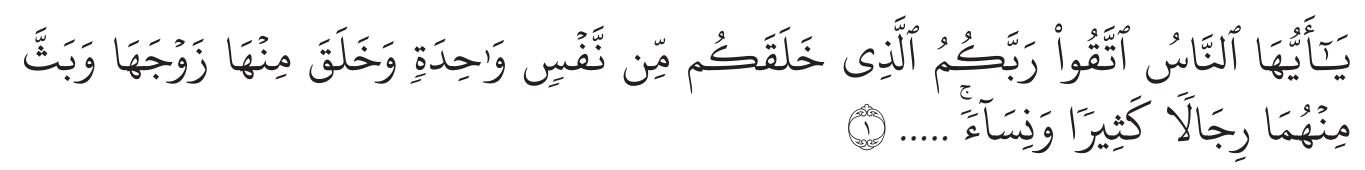

Terjemahannya:

Hai sekalian manusia, bertaqwalah kepada Tuhanmu yang telah menciptakan kamu dari jenis yang sama dan dari padanya Allah telah menciptakan pasangan dan daripada keduanya Allah memperkembangkan laki-laki dan perempuan yang banyak. (Qs. an-Nisa': 1)

\section{Dari segi kemanusiaan}

Sebelum Islam datang, sebagian bangsa Arab mengubur hiduphidup bayi perempuan karena alasan takut miskin atau tercemar

${ }^{8}$ As-Suyuthlmi, Lubab an Nuqul fi Asbab an Nuzul, (Kairo: Dar al Muqtim, 2008), hlm. 205

Sangaji Jurnal Pemikiran Syariah dan Hukum 
namanya. Hal ini disebutkan dalam al Qur'an surat an Nahl: 58-59 yakni:

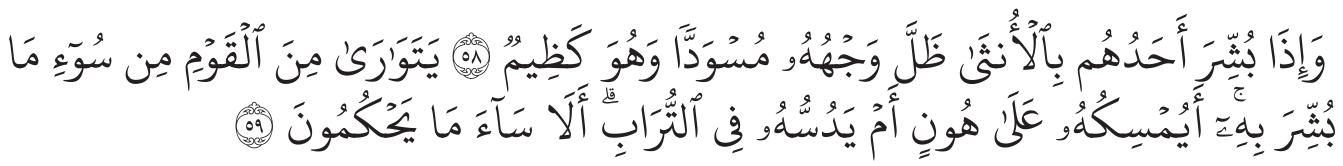

Terjemahannya:

Dan apabila seseorang dari mereka diberi kabar dengan kelahiran anak perempuan, hitam (merah padamlah) wajahnya dan ia sangat bersedih (marah). Ia menyembunyikan dirinya dari orang banyak disebabkan buruknya berita yang disampaikan kepadanya itu, (ia berfikir) apakah ia memeliharanya dengan menanggung kehinaan, atau menguburkannya ke dalam tanah (hidup-hidup). Ketauhilah, alangkah buruknya apa yang mereka tetapkan itu. (Qs. an-Nahl: 58-59)

Dalam hadits pun lebih rinci dijelaskan: ${ }^{9}$

Maka mereka memliki hak-hak dan kewajiban-kewajiban yang sama seperti yang dimiliki orang muslim lainnya" (HR Bukhari dan Nasa'i)

Dapat dikatakan, bahwasanya ayat-ayat di atas hanya sebagai contoh dari sekian banyak ayat-ayat al Qur'an yang secara terang menyebutkan kedua jenis laki-laki dan perempuan serta menyebutkan satu persatu arah dari perhatian al Qur'an terhadap mereka.

Al Qur'an menyebutkan masalah perempuan dalam berbagai surat dan ayat yang menyangkut dari berbagai sisi kehidupan, baik tentang hak dan kewajibannya. Adapun hak perempuan menurut al Qur'an yakni: ${ }^{10}$

\section{Hak perempuan untuk menerima mahar}

Salah satu keistemewaan syariat Islam dalam memberikan perlindungan dan penghormatan kepada kaum perempuan adalah adanya ketentuan mahar dalam perkawinan yang harus dipenuhi pihak laki-laki sebelum rumah tangga itu ditegakkan, sebagaimana firman Allah dalam surat an-Nisa: 4 yakni:

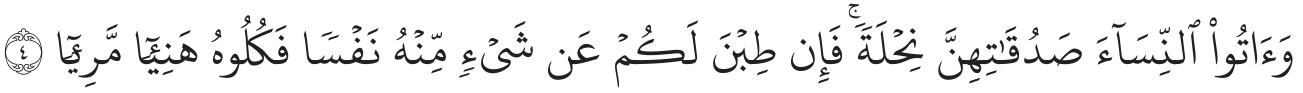

\footnotetext{
${ }^{9}$ Mujaid Kumkelo, Fiqihlm HLMam dalam Ortodoksi dan Liberalisme HLMak Asasi Manusia dalam Islam, (Malang: Setara Press, 2015), hlm. 94

${ }^{10}$ Mansour Fakihlm, Membincang Feminisme Diskursus Gender Perspektif Islam, (Surabaya: Risalahlm Gusti: 1996), hlm. 160
} 
Terjemahannya:

Berikan maskawin kepada perempuan (yang kamu nikahi) sebagai pemberian yang wajib. Kemudian jika mereka menyerahkan kepada kamu sebagian dari maskawin itu dengan senang hati, maka makanlah (ambillah) pemberian itu (sebagai makanan) yang sedap lagi baik akibatnya.

\section{Hak perempuan mendapat nafkah}

Setelah dilangsungkan akad nikah, suami berkewajiban kepada istrinya, sebagaimana firman Allah dalam surat al-Baqarah: 233

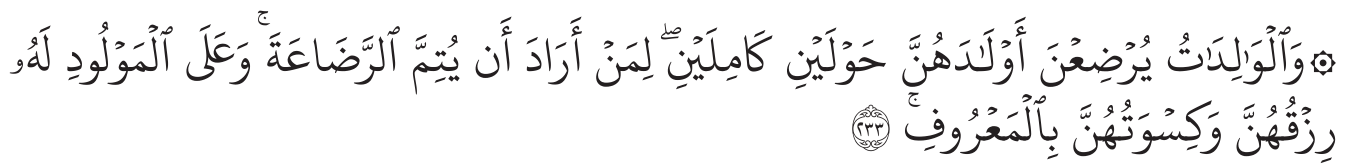

Terjemahannya:

Dan kewajiban ayah memberi makan dan pakaian kepada para ibu dengan cara yang ma'ruf.

Dapat dikatakan bahwasanya, ayat-ayat di atas hanya sebagai contoh dari sekian banyak ayat-ayat al Qur'an yang membahas tentang hak perempuan.

\section{Bentuk-Bentuk Ketidaksetaraan Gender Dalam Islam}

\section{Dalam Bidang Kewarisan}

Al Qur'an mengajarkan, anak perempuan mempunyai hak dalam pembagian harta pusaka. Akan tetapi, bagian anak laki-laki lebih banyak daripada bagian anak perempuan, yaitu bagian satu orang anak laki-laki sama dengan bagian dua orang anak perempuan. Jika seseorang meninggal dunia, dan ahli waris yang ia tinggalkan terdiri dari satu orang anak lakilaki dan satu orang anak perempuan, maka harta yang ditinggalkan dibagi tiga yakni: dua bagian untuk anak laki-laki dan satu bagian untuk anak perempuan. Sebagaimana dalam surat an-Nisa: 11 yakni:

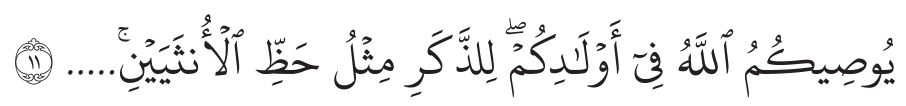

Ada beberapa riwayat apa yang menyebabkan turunnya ayat tersebut. Pertama, Jabir bin Abdullah berkata, suatu ketika aku sakit, 
maka Rasulullah SAW mengunjungiku. Pada waktu itu aku sedang tidak sadarkan diri. Setelah aku sadar, aku berkata kepadanya," ya Rasulullah, apa yang harus aku perbuat terhadap hartaku? Rasulullah SAW diam sehingga turunlah ayat tersebut.

Riwayat kedua, berkaitan dengan oleh janda Sa'ad bin Rabi' yang mengadu kepada Rasulullah SAW, bahwa dua anak perempuan Sa'ad sama sekali tidak mendapatkan harta warisan dari peninggalan bapak mereka yang terbunuh saat perang Uhud bersamamu. Saudara lakilaki Sa'ad mengambil semua harta peninggalan Sa'ad tanpa tersisa sedikit pun untuk kedua anak perempuannya. Padahal, mereka sangat membutuhkan harta tersebut untuk biaya pernikahan. Menanggapi keluhan janda Sa'ad tersebut, tidak lama kemudian, Allah menurunkan surat an Nisa: 11 tersebut.

Perlu diketahui bahwasanya, ayat di atas turun untuk menghapus sistem warisan yang berlaku pada masyarakat jahiliyyah, dimana mereka tidak memberikan hak waris kepada kaum wanita dan anak-anak. ${ }^{11}$

Hikmah yang bisa diambil dari ketentuan bagian anak laki-laki dua kalibagian anak perempuan adalah karena kewajiban dan tanggungjawab laki-laki lebih berat daripada perempuan. Laki-laki berkewajiban untuk membayar dan memberi mahar, serta memberi nafkah kepada istri dan anaknya. Sedangkan perempuan, apabila ia akan menikah maka, ia akan diberi mahar dan apabila ia telah menikah, segala keperluan hidupnya adalah merupakan tanggung jawab suaminya. ${ }^{12}$

Berdasarkan pemaparan di atas maka, dapat dipahami bahwasanya ketidaksamaan itu disebabkan oleh perbedaan tanggung jawab antara laki-laki dan perempuan bukan sebagai bentuk diskriminatif terhadap perempuan. Namun, walaupun demikian, ketentuan di atas dapat berubah bila para ahli waris laki-laki dan perempuan rela mengadakan perdamaian dalam pembagian harta warisan.

Jadi, selama laki-laki masih diposisikan sebagai penanggung jawab nafkah keluarga, membayar maskawin, membiayai ongkos-ongkos yang lain terhadap pihak lain yang menjadi tanggung jawabnya dan

\footnotetext{
${ }^{11}$ Kadar Yusuf, Tafsir Ayat Ahlmkam, (Pekanbaru: Amzahlm, 2013), hlm. 284

${ }^{12}$ Mansour Fakihlm, Membincang Feminisme Diskursus Gender Perspektif Islam, (Surabaya: Risalahlm Gusti, 1996), hlm.156
} 
sebagainya, maka pembagian 2:1 adalah adil.

Namun, Jika relasi telah berubah, maka ketentuan warisan pun bisa berubah. Sebab, ketentuan warisan merupakan logika lurus dari relasi suami istri. Justru sangat tidak adil, jika 2:1 dipertahankan, sementara relasi suami istri telah mengalami perubahan yang menuju kesetaraan gender. Karena inti agama adalah keadilan. ${ }^{13}$

\section{Dalam Bidang Pekerjaan}

Dalam pandangan Islam pekerjaan perempuan yang sesuai dengan kodratnya adalah di rumah dan perempuan bertanggung jawab di dalam rumahnya. Sedangkan laki-laki bertanggung jawab atas keperluan rumah tangganya seperti menyediakan pakaian, makanan, minuman, tempat tinggal, pendidikan untuk anak-anaknya. Namun, jika dalam keadaan terpaksa maka, perempuan juga boleh ikut serta dalam bekerja membantu suami.

Islam tidak melarang perempuan bekerja di luar rumah, tetapi perempuan harus memenuhi syarat-syarat yang ditentukan dalam syara' yang sesuai dengan kodratnya sebagai seorang perempuan, yakni:

1. Persetujuan wali.

Perempuan tidak diperbolehkan keluar dari rumahnya terkecuali atas izin walinya, karena perempuan adalah tanggung jawab walinya dan jika pun keluar atas dasar sesuatu yang sangat penting.

2. Terjaga dari fitnah

Beberapa sebab terjadinya fitnah terhadap perempuan di luar rumah yaitu bercampur baur dengan laki-laki ajnabi, berdua-duaan dengan laki-laki, berdandan yang berlebihan, dan menyebabkan perempuan masuk neraka. Diperbolehkan perempuan keluar rumah atau bekerja dengan syarat menjaga fitnah dan gangguan yang bisa menyebabkan terjadinya fitnah atas perempuan.

3. Pekerjaan yang tidak mengganggu perempuan sebagai istri dan seorang ibu

4. Pekerjaan yang sesuai dengan kodrat sebagai perempuan.

5. Pekerjaan yang baik

${ }^{13}$ Zaitunahlm Subhlman, Al-Qur'an dan Perempuan, (Jakarta: Kencana, 2015), hlm. 28

Sangaji Jurnal Pemikiran Syariah dan Hukum 
Segala pekerjaan yang menimbulkan kebaikan dan menambah amal kebaikan, tidak mengerjakan pekerjaan yang merusak moral.

Berdasarkan uraian di atas maka, dapat dipahami bahwa perempuan boleh bekerja sebagai wujud membantu suami, anak dan rumah tangganya, meskipun menafkahi keluarga itu merupakan kewajiban mutlak bagi suami, serta pekerjaan itu membawa kemaslahatan terhadap diri, keluarga, dan masyarakat. ${ }^{14}$

Pemikir modern Maududi, menyatakan bahwa tempat perempuan adalah di rumah. Perempuan tidak diberi kebebasan untuk melakukan pekerjaan di luar rumah agar dapat melaksanakan pekerjaan rumah tangga dengan baik. Jika terpaksa keluar, perempuan wajib memelihara kehormatannya. ${ }^{15}$

Kebolehan membantu bekerja suami tersebut dianalogikan kepada kebolehan memakan sebagian mahar atas kerelaan istri. ${ }^{16}$ Bila mahar itu sebagai pemberian yang wajib dari pihak suami kepada sang istri boleh dimakan oleh suami sebagiannya atas kerelaan isteri, maka boleh pula si istri bekerja untuk membantu suami, anak-anak, dan rumah tangganya, karena masalah tersebut tergolong dalam hal yang diperintahkan Allah SWT untuk tolong-menolong dan bantu-membantu dalam mengerjakan kebaikan, sebagaimana dalam surat al-Maidah: 2

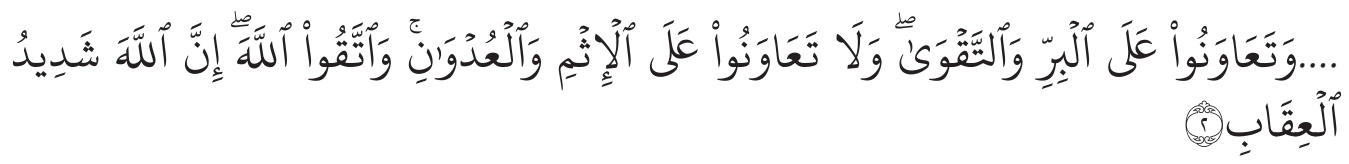

Berdasarkan ayat al Maidah:2, maka dapat dipahami bahwasanya, bekerja untuk membantu suami yang dalam keadaan susah termasuk perbuatan sangat baik dan tidak bertentangan dengan ajaran al-Qur an.

\section{Dalam Bidang Kepemimpinan}

Pembahasan tentang kepemimpinan terdapat dalam surat an Nisa: 34 yakni:

\footnotetext{
${ }^{14}$ Yusuf al Qardhlmawy, Ruang Lingkup Wanita Muslimahlm, (Jakarta: Pustaka Al Kautsar, 1996), hlm.238 hlm. xiii

${ }^{15}$ Sri Suhlmandjati, Bias Jender dalam Pemahlmaman Islam, (Yogyakarta: Gama Media, 2002),

${ }^{16}$ Mansour Fakihlm, Membincang Feminisme Diskursus Gender Perspektif Islam, (Surabaya: Risalahlm Gusti, 1996), hlm.61
} 


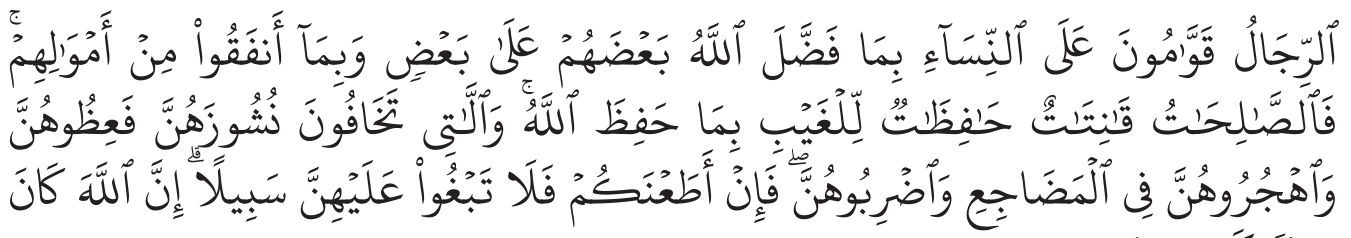

عَلِيَّا كْبِيَّا

Terjemahannya:

Kaum laki-laki adalah pemimpin bagi kaum perempuan. oleh karena Allah telah melebihkan sebagian mereka (laki-laki) atas sebagian yang lain (perempuan), dan karena mereka (laki-laki) telah menafkahkan sebagian dari harta mereka. Sebab itu maka perempuan yang saleh adalah yang ta'at kepada Allah lagi memelihara diri ketika suaminya tidak ada, karena Allah telah memelihara (mereka). Perempuan-perempuan yang kamu khawatirkan nuzhuznya, maka nasehatilah mereka dan pisahkanlah mereka ditempat tidur mereka, dan pukullah mereka. Kemudian mereka mentaatimu, maka janganlah kamu mencari-cari jalan untukmenyusahkannya. Sesungguhnya Allah Maha Tinggi lagi Maha Besar.

Kata qawwamuna pada an-Nisa : 34, tidak bermakna tunggal, tapi mempunyai tiga pengertian yakni:

1. Qawwamuna bisa berarti kepemimpinan, tapi kepemimpinan ini tidak permanen dan tidak disebabkan oleh kriteria biologis. Sebab di belakang dikaitkan dengan pemberian nafkah dan kelebihan lakilaki. Ketika kemampuan itu tidak ada maka, kepemimpinan itu bisa menjadi gugur

2. Qawwamuna dapat berarti orang yang bertanggung jawab atas keluarganya

3. Qawwamuna dapat diartikan kepemimpinan dalam keluarga.

Sedangkan kata "rijal" pada ayat di atas bukan berarti laki-laki secara umum, tapi suami karena konsideran lanjutan ayat tersebut adalah "karena mereka para suami menafkahkan sebagian harta untuk istri-istri mereka". Seandainya kata "laki-laki" adalah kaum pria pada umumnya tentu konsiderannya tidak begitu. Lebih jauh lagi lanjutan ayat tersebut jelas berbicara tentang persoalan para istri dan rumah tangga. Ayat tersebut secara jelas menyajikan pembagian kerja antara suami dan istri. ${ }^{17}$

${ }^{17}$ Zaitunahlm Subhlman, Al-Qur'an dan Perempuan, (Jakarta: Kencana, 2015), hlm. 94

Sangaji Jurnal Pemikiran Syariah dan Hukum 
Dr. Wahbah az Zuhaili, menerangkan bahwasanya, salah satu syarat untuk menjadi seorang pemimpin adalah berjenis kelamin laki-laki. Alasan mengapa pemimpin harus berkelamin laki-laki adalah karena beban tanggung jawab jabatan ini menuntut kemampuan yang sangat besar, yang biasanya tidak akan mampu dipikul oleh perempuan. ${ }^{18}$

Sebagaimana dikutip oleh Irsyadunnas, Ar Razimenafsirkan ayattersebut dengan (laki-laki bertanggung jawab terhadap pendidikan istrinya dan melindungi mereka). Dengan kata lain, laki-laki memang sudah ditetapkan oleh Allah sebagai pemimpin dan pengambil keputusan bagi mereka. ${ }^{19}$

Ibnu Qudamah mengatakan bahwasanya, "wanita manapun tidak boleh menjabat sebagai kepala negara dan tidak pula menjabat sebagai gubernur suatu wilayah. Karena itu, sepanjang sepengetahuan kami, Nabi dan para khalifah beliau serta orang-orang setelah mereka tidak pernah memberikan jabatan kepada wanita dalam masalah qadha'(pengadilan) ataupun kepemimpinan atas suatu wilayah. Seandainya hal itu diperbolehkan, pasti hal itu pernah terjadi pada era tertentu, ini jika berdasarkan pada kebiasaan. ${ }^{20}$ Dalam Hadits Nabi mengemukakan:

Tidak akan beruntung suatu kaum yang menyerahkan urusan mereka kepada seorang wanita.

Perkataan Nabi di atas merupakan respon dari Nabi saat memberikan informasi tentang raja Persia (Kisra) yang dengan congkaknya merobekrobek surat yang Nabi kirim kepadanya.Suatu ketika Kisra dibunuh oleh anak laki-lakinya, anak ini kemudian membunuh saudara-saudaranya. Ketika dia mati diracun, kepemimpinan kerajaan akhirnya dipegang oleh putrinya bernama Bawran binti Shiruyah bin Kisrah. Ternyata, tidak lama setelah itu, kerajaan Kisra hancur seperti yang disabdakan Nabi. Hadis ini ungkapan dalam kerangka pemberitahuan dan bukan dalam kerangka legitimasi hukum dan tidak memiliki relevansi hukum.

Dapat dipahami, hadis tersebut merupakan respon atas penobatan seorang putri Kisra Persia sebagai ratu, yang dianggap oleh Nabi

${ }^{18}$ Wahlmbahlm az-Zuhlmaili, al Fighlmul Islam wa Adillatuhlmu, (Damaskus: Daal al Fikr, 1989), hlm. 663

${ }^{19}$ Irsyadunnas, HLMermeneutika Feminisme, (Yogyakarta: Kaukaba, 2013), hlm 187

${ }^{20}$ Adnan bin Dhaifullah Alu asy- Syawabikah, Wanita Karir, (Jakarta: Pustaka asy-Syafi'i, 2010), hlm. 116 
Muhammad SAW tidak memiliki kemampuan memimpin pemerintahan. Penolakan Nabi Muhammad ini juga tidak didasarkan karena dia seorang perempuan, tapi lebih didasarkan kepada ketidakcakapan putri tersebut dalam memegang kendali pemerintahan. Sangat mungkin apabila perempuan yang memimpin bukan putri Kisra Persia, Nabi Muhammad SAW , tidak akan bersabda demikian.

Berdasarkan hal tersebut, maka dapat dipahami bahwasanya, Islam tidak melarang perempuan menjadi seorang pemimpin dalam urusan umum, bahkan menjadi kepala negara. Yang terpenting dia mampu melaksanakan tanggung jawab tersebut, namun dengan pertimbangan bahwa tidak ada laki-laki yang mampu mengemban jabatan tersebut. oleh karena itu, ayat-ayat tersebut harus dipahami secara kontekstual, karena kandungan petunjuknya bersifat temporal.

\section{Dalam Bidang Kesaksian}

Harga kesaksian dua orang perempuan sederajat dengan nilai kesaksian seorang laki-laki. Ketentuan ini bahkan disandarkan langsung kepada salah satu ayat al-Qur'an surat al-Baqarah: 282 yakni:

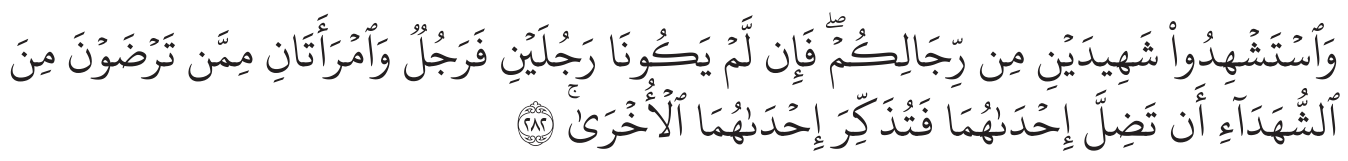

Terjemahannya:

Dan persaksikanlah dengan dua orang saksi dari orang-orang lelaki (diantaramu). Jika tak ada dua orang lelaki, maka (boleh) seorang lelaki dan dua orang perempuan dari saksi-saksi yang kamu ridhoi, supaya jika seorang lupa maka yang seorang mengingatkannya.

Hakikatnya ayat di atas mengakomodasi realitas. Selain karena memang konstruk sosial-budaya masyarakat Arab saat itu yang masih menganggap rendah perempuan, juga kondisi perempuan waktu itu yang pada umumnya belum terbiasa melakukan urusan-urusan perdagangan, utang-piutang, dan urusan publik lainnya, sehingga perempuan muda lupa untuk mengingat suatu peristiwa transaksi ekonomis yang terjadi. ${ }^{21}$ Sebagaimana yang diungkapkan oleh al-Qur'an, yakni:

${ }^{21}$ Nuruzzaman, Islam Agama Ramahlm Perempuan, (Yogyakarta: LKIS, 2013), hlm. 128

Sangaji Jurnal Pemikiran Syariah dan Hukum 


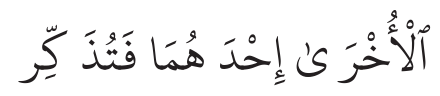

Supaya jika perempuan yang satu lupa, yang lain mengingatnya

Namun, bila dihubungkan dengan era modern saat ini, orang perempuan bisa sendirian menjadi saksi dalam suatu urusan, tanpa ada yang mempersoalkannya, Namun masih bisa dipertanggungjawabkan. Pada masa lalu transaksi-transaksi ekonomi dilakukan dengan cara-cara yang sederhana, berbeda di era modern saat ini yang menggunakan kwitansi atau notaris dan sebagainya.

Apabila ayat-ayat al-Qur'an dipahami secara seimbang, proporsional, dan terintegrasi satu sama lain, maka semua ayat yang tercantum dalam al-Qur'an tidak akan saling bertentangan.

Sumber ajaran Islam (al Qur'an dan Hadis) tidak saja dapat dipahami secara normatif, pemahaman secara kontekstual sangat diperlukan. Tafsir atas teks suci sejatinya tidak hanya dalam bingkai pembenaran terhadap teks atau pembelaan pada Tuhan semata, melainkan harus menyentuh personal-personal riil dalam masyarakat, seperti pembebasan kemiskinan, pendidikan, dan segala bentuk penindasan.

Menganalisa peristiwa masa lalu harus dilihat dalam konteks sejarahnya, demikian pula peristiwa di tempat yang berbeda. Membaca masa lalu dengan konteks sekarang atau peristiwa yang terjadi di tempat yang berbeda dan dibaca dengan konteks ke Indonesiaan akan membuat pemahaman tidak obyektif dan cenderung menghakimi situasi tertentu. ${ }^{22}$

Syariat Islam mengandung beberapa varian yang harus dipahami secara utuh, seperti hukum, tujuan hukum, dalil, dan ijtihad. Hal ini menunjukkan bahwasanya syariat tidak hanya hukum belaka, karena ada varian lain yang sangat penting yaitu maqashid asy-syari'ah dan inti dari maqashid asy-syari'ah yaitu kemaslahatan, yang berarti mengambil manfaat dan menghindari terjadinya kerusakan, ${ }^{23}$

Hal ini menunjukkan bahwa agama tidak hanya menekankan pada aspek ritual dan ibadah semata, tetapi juga membawa misi kemaslahatan bagi manusia (al maslahah al-'ammah)

${ }^{22}$ Aksin Wijaya, Menggugat Otentisitas Wahlmyu Tuhlman, (Yogyakarta: Safiria Insania Press, 2004), hlm. 133

${ }^{23}$ Zaitunahlm Subhlman, Al-Qur'an dan Perempuan, (Jakarta: Kencana, 2015), hlm. 28 


\section{Operasionalisasi Pendidikan Gender Dalam Studi Islam}

Hakikatnya tujuan Islam berbasis gender untuk menata ulang pemahaman teks-teks agama yang dituduh sebagai sumber kekerasan terhadap perempuan. bahkan, tidak sedikit aktivis gender yang melecehkan fikih dengan menuduhnya menjadi penyebab utama terjadinya ketidakadilan dan kekerasan seksual terhadap perempuan. aturan ibadah yang disusun dalam kitab fiqih dicurigai sangat diskriminatif karena melarang mutlak perempuan menjadi imam bagi laki-laki, menjadi muadzin, khatib Jum'at dan lain-lain.

Sebagian aktivis gender juga menyatakan bahwa teks al Qur'an dan hadis mempunyai standar ganda dalam menempatkan perempuan. Menurut penggiat gender lainnya mengemukakan bahwa hal ini disebabkan penggunaan bahasa Arab sebagai bahasa wahyu yang sejak awalnya mengalami bias gender, baik dalam kosakata, maupun dalam strukturnya.

Oleh karena itu, setidaknya ada tiga model kajian yang terkait dengan gender dan studi Islam yakni:

1. Penelitian yang berangkat dari kajian murni yang value free, dalam arti bukan berangkat dari prinsip dan tujuan mewujudkan keadilan gender, namun hanya sekedar untuk mendiskripsikan isu-isu tersebut dalam berbagai disiplin keilmuan. Maka, bentuk kajiannya pun harus berupa normatif-deskriptif. Misalnya, isu-isu gender dalam perspektif ini dikaji dengan menggunakan pendekatan keilmuan murni seperti tafsir, hadis, fikih dan lain sebagainya. Sehingga, informasinya lebih bersifat deskriptif, tidak mempunyai kepentingan untuk melakukan suatu perubahan.

2. Penelitian yang berangkat dari kajian dengan pendekatan ilmu sosial dan humaniora dengan mengkaji isu-isu perempuan dengan berpijak pada paradigma feminis dan teori sosial kritis.

Dalam hal ini dapat disarikan ke dalam beberapa langka yakni: Pertama, mengubah pandangan budaya yang selalu menempatkan perempuan dalam posisi subordinat. Kedua, melakukan dekonstruksi terhadap pemahaman keagamaan yang tidak kondusif terhadap peran gender. Ketiga, merevisi sistem pendidikan agama yang 
terlalu menekankan pada aspek kognitif semata, dan merumuskan suatu sistem pendidikan agama yang dapat mengubah perilaku keagamaan. Keempat, merevisi sejumlah peraturan yang bias gender dan tidak bersahabat pada perempuan. ${ }^{24}$

3. Penelitian yang berangkat dari kajian dengan pendekatan ilmu sosial dan humaniora dengan mengkaji isu-isu perempuan dengan paradigma feminis berpusat pada analisis gender. Artinya, semua bidang dalam kajian Islam dapat membahas persoalan-persoalan gender dan perempuan tersebut.

4. Penelitian yang berangkat dari kajian dengan pemetaan isu-isu gender dalam studi Islam.

Rita M Gross mengemukakan, bukanlah perkara yang sederhana untuk mengintegrasikan agama dan gender. Agama dan gender mempunyai tema kajian yang sama kompleksnya dan sama-sama membangkitkan emosi. gender dan agama adalah sistem kepercayaan yang saling bertentangan dan sarat emosi yang memberi pengaruh langsung terhadap kehidupan orang banyak.

Hingga kini, internasionalisasi kajian wanita dilakukan dengan dua cara yakni: ${ }^{25}$

a. Menekankan kesamaan diantara perempuan di seluruh dunia. Isuisu yang disetujui difokuskan pada masalah keibuan dan struktur keluarga. Walaupun isu tersebut dialami semua perempuan dan disuarakan kepentingan mereka, tetapi ia juga berkaitan erat dengan keberagaman budaya, kelas, bangsa dan orientasi seksual sehingga menghasilkan perbedaan pandangan tentang arti ibu dan struktur keluarga.

b. Pendekatan yang lebih hierarkis dengan melihat budaya barat sebagai model ideal sehingga budaya-budaya lain harus dipahami dari sudut pandang barat. Pendekatan ini melahirkan program women and development.

\footnotetext{
${ }^{24}$ Siti Musdahlm Mulia, Islam dan Inspirasi Kesetaraan Gender, (Yogyakarta: Kibar Press, 2006), hlml. 101-102

${ }^{25} \mathrm{hlmttp}: / /$ www.google.co.id/amp/m.republika.co.id
} 


\section{Kesimpulan}

Berdasarkan pemaparan di atas, maka ditarik beberapa kesimpulan, Pertama, Gender merupakan suatu konsep yang melihat peran lakilaki dan perempuan dari aspek sosial dan budaya. Hakikatnya Islam menempatkan perempuan pada posisi yang sama dengan laki-laki, tidak ada perbedaan diantara keduanya. Yang membedakan hanyalah dari sisi ketakwaan. Kedua, Bentuk ketidakadilan gender dapat dilihat melalui berbagai manifestasi seperti marginalisasi, subordinasi, pembentukan sreotipe (pelabelan), kekerasan(violence) maupunbebankerja. Dikarenakan sudah sangat membudaya, sebagian kalangan menganggap bahwa bias gender tersebut merupakan kodrat dari Tuhan. Ketiga, Masalah gender dalam studi Islam hingga kini masih memunculkan banyak pertanyaan dan pertikaian. Namun, dapat dipahami bahwa menjadikan pola fikir feminis barat sebagai kiblat studi gender adalah kekeliruan yang sangat mendasar. Dalam Islam dan tradisi masyarakat Indonesia, perempuan ditempatkan pada tempat yang terhormat, sebagai hamba Allah yang setara kedudukannya dengan laki-laki, meskipun dengan peran yang berbeda.

\section{Daftar Pustaka}

Adnan bin Dhaifullah Alu asy- Syawabikah, Wanita Karir, (Jakarta: Pustaka asy-Syafi'i, 2010.

Aksin Wijaya, Menggugat Otentisitas Wahyu Tuhan, Yogyakarta: Safiria Insania Press, 2004.

As-Suyuthi, Lubab an Nuqul fi Asbab an Nuzul, Kairo: Dar al Muqtim, 2008 Irsyadunnas, Hermeneutika Feminisme, Yogyakarta: Kaukaba, 2013.

Kadar Yusuf, Tafsir Ayat Ahkam, Pekanbaru: Amzah, 2013.

Musdah Mulia, Indahnya Islam Menyuarakan Keseteraan \& Keadilah Gender, Yogyakarta: SM \& Naufan Pustaka, 2014.

Mufidah, Psikologi Keluarga Islam Berwawasan Gender, Malang: Uin Malang Press, 2008.

Mujaid Kumkelo, Fiqih Ham dalam Ortodoksi dan Liberalisme Hak Asasi Manusia dalam Islam, Malang: Setara Press, 2015.

Sangaji Jurnal Pemikiran Syariah dan Hukum 
Sri Suhandjati, Bias Jender dalam Pemahaman Islam, Yogyakarta: Gama Media, 2002.

Wahbah az-Zuhaili, al Fighul Islam wa Adillatuhu, Damaskus: Daal al Fikr, 1989

Zaitunah Subhan, Al-Qur'an dan Perempuan, Jakarta: Kencana, 2015.

Yusuf al Qardhawy, Ruang Lingkup Wanita Muslimah, Jakarta: Pustaka Al Kautsar, 1996. 